\title{
PENERAPAN PENDEKATAN KONTRUKTIVISME BERBANTUAN MEDIA AUDIO VISUAL UNTUK MENUMBUHKAN MINAT BELAJAR SISWA PADA MATA PELAJARAN PPKN
}

\section{RINI SUSILOWATI}

SMA Negeri 3 Singkawang

e-mail: $\underline{\text { Rini1276@yahoo.co.id }}$

\begin{abstract}
ABSTRAK
Penelitian ini bertujuan untuk: 1). Menumbuhkan Minat Belajar Siswa melalui Pendekatan Kontruktivisme Berbantuan Media Audio Visual pada Mata Pelajaran PPKn di Kelas XI IPA1 SMA Negeri 3 Singkawang. 2) Stategi yang dilakukan oleh guru dalam Menumbuhkan Minat Belajar Siswa melalui Pendekatan Kontruktivisme Berbantuan Media Audio Visual pada Mata Pelajaran PPKn di Kelas XI IPA1 SMA Negeri 3 Singkawang. Pembelajaran PPKn dengan menggunakan pendekatan konstruktisme berbantuan media audio-visual dilakukan agar pembelajaran lebih variatif sehingga menarik minat belajar siswa, maka perlu dipersiapkan media yang dapat disesuaikan dengan irama belajar mereka, Media yang digunakan harus menarik minatnya untuk belajar. Teknik pengumpulan data dalam penelitian ini adalah: teknik pengukuran (teknik tes) dan teknik Observasi Langsung. Sedangkan Alat pengumpul data dalam Penelitian ini meliputi tes, observasi, dan wawancara. Hasil penelitian menunjukan bahwa penerapan Pendekatan Kontruktivisme Berbantuan Media Audio Visual pada Mata Pelajaran PPKn dapat menarik minat belajar siswa. Dari 28 siswa hampir seluruh siswa 26 orang atau setara dengan $82,68 \%$ mencapai ketuntasan belajar minimum yang ditetapkan pada pembelajaran PPKn sedangkan 2 orang atau setara dengan 7,14\% memperoleh hasil belajar di bawah KKM yaitu 70 .
\end{abstract}

Kata Kunci: Konstruktivisme, Media Audio-visual dan Minat belajar

\section{ABSTRACT}

This study aims to: 1). Growing Student Interest in Learning through a Constructivism Approach Assisted by Audio Visual Media in Civics Subjects in Class XI IPA1 SMA Negeri 3 Singkawang. 2) The strategy undertaken by the teacher in Fostering Student Interest in Learning through a Constructivism Approach Assisted by Audio Visual Media in Civics Subjects in Class XI IPA1 SMA Negeri 3 Singkawang. Civics learning using a constructivism approach assisted by audiovisual media is carried out so that learning is more varied so that it attracts student learning interest, it is necessary to prepare media that can be adapted to their learning rhythm. The media used must attract interest in learning. The data collection techniques in this study were: measurement techniques (test techniques) and direct observation techniques. While the data collection tools in this study include tests, observations, and interviews. The results showed that the application of the Constructivism Approach Assisted by Audio Visual Media in Civics Subjects could attract students' interest in learning. Of the 28 students, almost all 26 students or equivalent to $82.68 \%$ achieved the minimum learning completeness set in Civics learning while 2 students or equivalent to $7.14 \%$ obtained learning outcomes below the KKM, which is 70 .

Keywords: Constructivism, Audio-visual Media and Interest in learning

\section{PENDAHULUAN}

Pendidikan Pancasila dan Kewarganegaraan (PPKn) Merupakan sebuah mata pelajaran di Sekolah menengah atas (SMA) yang memfokuskan pada pembentukan warganegara yang memahami dan mampu melaksanakan hak-hak dan kewajibannya untuk menjadi warganegara Indonesia yang cerdas, terampil dan berkarakter sebagaimana diamanatkan oleh Pancasila dan UUD 1945. Guna mewujudkan tujuan pembelajaran itu maka guru dan siswa harus mampu 
mewujudkan proses pembelajaran yang berkualitas. Keduanya sangat kompeten karena dalam unsur pendidikan antara guru dan siswa menunjukkan sebuah sistem yang saling terkait antara satu dengan lainnya. Pihak siswa akan lebih cepat menguasai materi yang disampaikan guru, jika guru menyajikan materi melalui penggunana media dan penerapan strategi atau teknik pembelajaran yang mampu memberikan kemudahan saat proses mentranformasikan nilai dalam pembelajaran. Guru juga perlu mengarahkan saat pembelajaran agar siswa lebih interaktif dalam pembelajaran. Dilihat dari banyaknya konsep serta kesukaran materi, materi integrasi nasional dalam bingkai bhineka tunggal ika sulit dipahami oleh siswa hanya dengan membaca buku ataupun mendengarkan penjelasan guru secara lisan.

Strategi pembelajaran yang digunakan adalah strategi yang berkaitan langsung dengan halhal yang terjadi dan dialami oleh siswa. Guru harus pandai mengaitkan materi pelajaran dengan realita yang ada serta dituntut berusaha agar materi yang disampaikan dapat dimengerti oleh siswa . Kenyataan yang terjadi selama ini belajar PPkn penuh dengan hafalan dan membahas hal-hal yang abstrak. Pentingnya integrasi nasional bagi bangsa Indonesia, syarat-syarat terjadinya integrasi nasional serta pentingnya kesadaran bela Negara bagi bangsa Indonesia yang disertai dengan contohnya tidak mampu dijelaskan hanya dengan metode ceramah saja, oleh karena itu untuk membangun kemampuan awal siswa dalam memahami konsep yang terdapat pada mata pelajaran PPKn diperlukan suatu media yang memungkinkan siswa agar dapat menggunakan alat indera untuk mempelajari sesuatu serta mudah diingat apa yang dipelajari. Pada hakikatnya proses belajar mengajar merupakan sebuah sistem, yang di dalamnya memiliki berbagai komponen yang saling bekerja sama dan terpadu 2 untuk mencapai tujuan pembelajaran. Komponen - komponen tersebut meliputi tujuan pengajaran, guru dan peserta didik, bahan pelajaran, metode, strategi dan pendekatan dalam belajar mengajar, alat atau media, sumber pelajaran dan evaluasi. Masalah pendidikan tidak dapat lepas dari masalah pembelajaran, karena pembelajaran merupakan inti dari proses peningkatan kualitas pendidikan.

Komunikasi sangat memegang peranan penting dalam proses belajar mengajar. Agar komunikasi antara guru dan siswa berlangsung baik dan informasi yang disampaikan dapat diterima dengan baik, salah satu usaha yang 3 dilakukan yaitu dengan menggunakan media pengajaran baik secara audio mapupun visual. Selain itu pendekatan konstruktivisme berbantuan media yang berbasis audio-visual tersebut dapat sebagai perantara dalam rangka memperlancar pencapaian tujuan dari pelaksanaan pendidikan sekolah. Media pengajaran harus bersifat menyalurkan pesan dan dapat merangsang pikiran, perasaan, dan kemauan siswa, sehingga dapat mendorong terjadinya proses belajar pada dirinya. Selain itu juga media pembelajaran diharapkan dapat memberikan pengalaman belajar baru bagi siswa. Lebih jauh lagi dengan penggunaan media dalam proses pembelajaran, diharapkan tidak hanya perkembangan kognitif siswa semakin baik, tetapi juga aspek-aspek yang lain seperti psikomotorik dan afektifnya. Pada hakikatnya dalam proses pembelajaran, pengembangan potensi-potensi siswa harus dilakukan secara menyeluruh dan terpadu. Pengembangan potensi siswa yang tidak seimbang pada gilirannya akan menjadikan pendidikan bersifat particular dan parsial. Jadi sangat keliru jika guru hanya bertanggungjawab menyampaikan materi pelajaran pada bidang studinya saja (Gordon dalam Aunurrahman, 2016:4). Guru berperan penting dalam membentuk watak bangsa melalui pendidikan. Dengan pemanfaatan media pembelajaran maka diharapkan dapat juga terjadi perubahan sikap siswa kearah yang lebih baik, karena di dalam media pembelajaran selayaknya tidak hanya berisi pengembangan kognitif saja tetapi juga semua ranah pembelajaran.

Konstruktivis merupakan landasan berpikir (filosofi) pembelajaran kontekstual. Pengetahuan dibangun oleh siswa melalui kegiatan eksplorasi dan diskusi degan temannya. Pengetahuan bukanlah seperangkat fakta, konsep, atau kaidah yang siap untuk diambil dan diangkat, tetapi siswa harus mengkonstruksi pengetahuannya sendiri. Menurut Trianto (2017:35) menyatakan bahwa: Teori konstruktivisme adalah siswa harus menemukan sendiri dan 
mentranformasikan informasi kompleks, mengecek informasi baru dengan aturan-aturan lama dan merevisinya apabila aturan-aturan itu tidak lagi sesuai. Dengan menggunakan pendekatan konstuktivistik, pembelajaran dilakukan bersama-sama oleh guru. dengan peserta didik dengan produk kegiatan adalah membangun persepsi dan cara pandang siswa mengenai materi yang dipelajari, mengembangkan masalah baru, dan membangun konsep-konsep baru dengan menggunakan evaluasi yang dilakukan pada saat kegiatan pembelajaran berlangsung. Selanjutnya strategi pembelajaran konstruktivisme atau "student-centered learning strategies adalah: 1). Belajar aktif. 2). Belajar mandiri. 3). Belajar kooperatif dan kolaboratif. 4).Generative learning. 5). Model pembelajaran kognitif. Dalam memperoleh pengetahuan siswa diawali dengan diadopsinya pengalaman baru sebagai hasil interaksi dengan lingkungan. Pengalaman baru tersebut kemudian dibandingkan dengan konsepsi awal yang telah dimiliki siswa sebelumnya. Jika pengalaman baru tersebut tidak sesuai dengan konsepsi awal siswa, maka terjadi ketidakseimbangan dalam struktuf kognitifnya. Peran guru dan siswa dalam pembelajaran konstruktivis, dalam kegiatan belajar mengajar guru berperan sebagai mediator dan fasilitator yang membantu yang membantu agar proses belajar siswa berjalan dengan baik. Secara garis besar media dapat dikategorikan menjadi empat macam, yaitu media visual, media media dengar, media proyeksi (proyected still), dan proyected motion media. Media adalah sarana untuk meningkatkan kegiatan proses belajar mengajar. Mengingat banyaknya macam media maka guru harus dapat berusaha memilihnya dengan cermat agar dapat digunakan dengan tepat. Apabila media itu membawa pesan-pesan atau informasi yang bertujuan intruksional atau mengandung maksudmaksud pengajaran maka media itu disebut media pengajaran.

Berdasarkan Uraian diatas penulis tertarik untuk meneliti tentang" penerapan pendekatan Konstruktivisme Berbantuan Media Audio Visual Untuk menumbuhkan minat belajar siswa pada mata pelajaran PPKn". Adapun rumusan masalah adalah bagaimana menumbuhkan minat belajar siswa dengan penerapan pendekatan konstruktivisme berbantuan media audio visual pada mata pelajaran PPKn. Sedangkan tujuan penelitian ini adalah untuk memperbaiki proses pembelajaran khususnya pada Mata Pelajaran PPKn Sedangkan secara khusus penelitian ini bertujuan untuk memberikan gambaran tentang: 1) Menumbuhkan Minat Belajar Siswa melalui Pendekatan Kontruktivisme Berbantuan Media Audio Visual pada Mata Pelajaran PPKn. 2) Stategi yang dilakukan oleh guru dalam Menumbuhkan Minat Belajar Siswa melalui Pendekatan Kontruktivisme Berbantuan Media Audio Visual pada Mata Pelajaran PPKn.

\section{METODE PENELITIAN}

Subjek penelitian tentang Penerapan pendekatan konstruktivisme berbantuan media audio visual untuk menumbuhkan minat belajar siswa pada mata pelajaran PPKn yaitu siswa kelas XI IPA1 yang terdiri dari 18 orang siswa perempuan dan 10 siswa laki-laki. Penelitian ini dilaksanakan di SMA Negeri 3 Singkawang dengan waktu pelaksanaan penelitian selama 2 bulan.

Metode penelitian yang digunakan dalam penelitian ini adalah metode deskriptif. Metode deskriptif merupakan metode penelitian yang berusaha menggambarkan dan menginterprestasikan objek sesuai dengan apa adanya. Metode ini digunakan untuk mengungkapkan keadaan sebenarnya tentang Penerapan pendekatan konstruktivisme berbantuan media audio visual untuk menumbuhkan minat belajar siswa pada mata pelajaran PPKN. Seberapa besar kontribusi yang diberikan dengan kegiatan ini, sehingga akan tercapai kegiatan belajar yang menyenangkan dan menarik minat bagi siswa.

Data pada penelitian ini menggunakan data deskriptif, kuantitatif dan kualitatif (Rukayat, 2018:2-10). Data kuantitatif diperoleh dari instrumen tes hasil belajar dan observasi minat belajar siswa. Data kuantitatif dan deskriptif diperoleh dari instrumen observasi keterlaksanaan pembelajaran, angket atau catatan lapangan. Teknik pengumpulan data pada Penelitian Tindakan Kelas ini dengan menggunakan dua teknik yaitu teknik tes dan teknik non tes. Sumber data 
penelitian akan diperoleh langsung dari observasi minat belajar siswa, catatan lapangan, angket siswa dan hasil belajar siswa. Teknik pengumpulan data yang digunakan dalam penelitian ini yaitu trianggulasi yaitu observasi, diskusi dan dokumentasi. Teknik pengumpulan data dalam penelitian ini adalah: teknik pengukuran (teknik tes) dan teknik Observasi Langsung. Pengamatan kepada guru oleh teman sejawat untuk melihat apakah Penerapan pendekatan konstruktivisme berbantuan media audio visual untuk menumbuhkan minat belajar siswa pada mata pelajaran PPKn sudah sesuai dengan langkah-langkah di dalam rencana pelaksanaan pembelajaran.

Alat pengumpul data dalam Penelitian ini meliputi tes, observasi, dan wawancara. 1).Tes adalah tes tertulis yang dilakukan oleh guru untuk mengetahui kemampuan siswa setelah mengikuti pembelajaran PPKn dengan pendekatan konstruktivisme berbantuan media audio visual. 2). Pedoman observasi adalah alat pengumpul data dengan teknik observasi langsung, memuat indikator-indikator yang diamati. Adapun pedoman observasi yang dilakukan dengan menggunakan lembar observasi. 3). Pedoman wawancara dalam penelitian ini dibuat dalam bentuk semi terstruktur yang berisi sejumlah pertanyaan yang berkaitan erat dengan indikator penelitian. Tujuannya adalah agar penulis memperoleh informasi yang lengkap mengenai pendapat atau sikap siswa dan teman sejawat tentang pembelajaran dengan menggunakan pendekatan konstruktivisme berbantuan media audio visual.

\section{HASIL DAN PEMBAHASAN}

\section{Hasil}

Pembelajaran dilakukan dengan menerapkan pendekatan konstruktivisme berbantuan Media Audio Visual. Pendekatan pembelajaran konstruktivistik dilaksanakan guru dengan cara mengaitkan materi pelajaran yang dipelajari ke dalam dunia nyata siswa. Kegiatan tersebut dilakukan guru dengan cara menyampaikan materi yang dipelajari pada saat kegiatan ekplorasi dan konfirmasi, yaitu dengan mengilustrasikan materi-materi tersebut ke dalam sebuah gambar sebagai contoh integrasi Nasional dalam bingkai Bhineka tunggal ika. Guru juga menyampaikan materi dengan bantuan media audio visual (CD pembelajaran), dengan tujuan agar siwa lebih tertarik dan fokus dalam mengikuti pelajaran dengan menayangkan gambar-gambar dan video. Aktivitas yang muncul pada kegiatan konstruktivistik antara lain melihat gambar dan tulisan, membaca serta mendengarkan penjelasan guru, berdiskusi kelompok dalam mengerjakan LKS. Penerapan pendekatan konstruktivistik pada pelajaran PPKn mampu membangun pengetahuan siswa secara mendalam dari penafsiran-penafsiran yang berasal dari interaksi para siswa terhadap lingkungan fisik maupun sosial. Sebelum kegiatan proses pembelajaran berlangsung dengan menggunakan media audio-visual, penulis dalam hal ini guru mata pelajaran PPKn terlebih dahulu menjelaskan tujuan penggunaan media audio visual dan menjelaskan prosedur penggunaan media. Adapun Tahapan-tahapan (Fase) pembelajaran dengan pendekatan konstrutivisme berbatuan media audio visual menurut Suyatna (2007:33-34) yaitu: 1). Eksplorasi, 2) Klarifikasi, dan 3). Aplikasi.

Berdasarkan langkah-langkah di atas, secara operasional kegiatan guru dan siswa selama proses pembelajaran di dalam kelas dapat dijabarkan sebagai berikut:

A. Tahapan (Fase) Eksplorasi

\section{Kegiatan Guru}

- Guru membagi siswa kedalam beberapa kelompok (4-5 orang siswa) dan tiap-tiap kelompok dipilih ketua untuk mengkoordinir jalannya diskusi.

- Guru memberikan penjelasan mengenai petunjuk penggunaan media audiovisual yang akan diberikan kepada siswa.

- Guru memperhatikan dan mengamati siswa dalam penggunaan media audiovisual yang berisikan penjelasan-penjelasan materi lengkap beserta contoh-contohnya pada kelompok siswa masing-masing. 
2. Kegiatan Siswa

- Membentuk kelompok sesuai dengan yang sudah ditetapkan oleh guru dan berusaha dapat bekerjasama dalam kelompok.

- Memperhatikan penjelasan guru tentang petunjuk belajar yang terdapat di media audio visual sehingga dapat mengaplikasikan kembali di dalam kelompok.

- Siswa melihat gambar dan tulisan, membaca serta mendengarkan penjelasan yang ada di dalam media audiovisual bersama siswa yang lain di dalam satu kelompok.

B. Tahapan (Fase) Klarifikasi

1. Kegiatan Guru

- Guru memberikan kesempatan kepada siswa dalam kelompok untuk bertanya tentang materi yang telah mereka dapat pada media audiovisual.

- Untuk menumbuhkan partisipasi aktif dalam merumuskan pengetahuan siswa guru memberikan masalah yang terjadi di lingkungan sekitar untuk dapat dipecahkan secara berkelompok.

2. Kegiatan Siswa

- Siswa memberikan beberapa pertanyaan seputar materi yang terdapat dalam media audiovisual yang mereka anggap perlu diperjelas kembali oleh guru.

- Mencoba alternatif pemecahan dengan teman sekelompok, mencatat pengamatan, serta mengembangkan ide-ide baruyang berkaitan dengan permasalahan yang diberikan oleh guru.

C. Tahapan (Fase) Aplikasi

1. Kegiatan Guru

- Guru memberikan kesempatan kepada tiap-tiap kelompok untuk melaporkan hasil diskusinya di depan kelas dan kelompok yang belum mendapatkan kesempatan dapat menanggapi hasil diskusi dari kelompok yang presentasi.

2. Kegiatan Siswa

- Setiap kelompok secara bergantian, memaparkan hasil diskusi mengenai masalah yang diberikan oleh guru di depan kelas. Setelah penerapan pendekatan kontruktivisme berbantuan media audio-visual digunakan dalam proses pembelajaran di kelas, diketahui terjadi perubahan dalam peningkatan pemerolehan hasil belajar siswa pada ranah kognitif. Ketika dilakukan evaluasi diperoleh hasil yang jauh meningkat jika dibandingkan dengan hasil belajar pada materi Integrasi Nasional dalam bingkai Bhineka tunggal ika pada mata pelajaran PPKn sebelumnya dengan metode ceramah saja.

Setelah penerapan pendekatan kontruktivisme berbantuan media audio-visual digunakan dalam proses pembelajaran di kelas, diketahui terjadi perubahan dalam peningkatan pemerolehan hasil belajar siswa pada ranah kognitif. Ketika dilakukan evaluasi diperoleh hasil yang jauh meningkat jika dibandingkan dengan hasil belajar pada materi integrasi nasional dalam bingkai bhineka tunggal ika pada mata pelajaran PPKn sebelumnya dengan metode ceramah saja. Dari 28 siswa hampir seluruh siswa 26 atau setara 82,68 \% siswa memperoleh hasil belajar sesuai KKM sedangkan 2 atau setara 7,14\% siswa memperoleh hasil belajar kurang dari KKM yaitu 70. Setelah itu penulis melakukan observasi terhadap subjek (siswa) dalam mengoperasikan media tersebut. Ketika ditanya respon mereka terhadap penerapan Pendekatan Kontruktivisme berbantuan media, dan tanggapan mereka terhadap media yang digunakan tersebut, semuanya menyatakan mudah dipahami. Untuk tampilan gambar, warna, animasi, musik, dan suara juga dikatakan menarik. Mereka menyatakan jika pembelajaran dengan memanfaatkan media tersebut tentu sangat menyenangkan dan mengasyikkan. Apa lagi saat dikatakan bahwa mereka dapat menyesuaikan proses belajar menggunakan CD tersebut dengan irama belajarnya masing-masing, selain itu 
mereka dapat melakukan proses pembelajaran dimana dan kapan saja mereka mau. Hal ini dapat lebih jelas terlihat dalam tabel berikut ini:

Tabel 1. Data Hasil Evaluasi sebelum dan sesudah penerapan Pendekatan Konstruktivisme Berbantuan media Audio visual

\begin{tabular}{|c|c|c|c|}
\hline No & Nama Siswa & $\begin{array}{l}\text { Sebelum } \\
\text { Penerapan }\end{array}$ & $\begin{array}{c}\text { Sesudah } \\
\text { Penerapan }\end{array}$ \\
\hline 1 & Ade Putri Orientasi & 70 & 80 \\
\hline 2 & Affan Nuzhandi Amnestito & 70 & 76 \\
\hline 3 & Aldha Shalshabilla. T & 75 & 95 \\
\hline 4 & Ankhasa Dwi Arjuna & 60 & 70 \\
\hline 5 & Arimbi Aprilia Putri & 65 & 80 \\
\hline 6 & Cassandra Vienna Panjaitan & 55 & 75 \\
\hline 7 & Christoforus Putra Septori Pesi & 45 & 58 \\
\hline 8 & Deswita Malika Riony & 60 & 75 \\
\hline 9 & Fandri Zynabil & 60 & 70 \\
\hline 10 & Gustini andriyani & 70 & 75 \\
\hline 11 & Habli rahman & 70 & 76 \\
\hline 12 & Ilham Khaira Amaldi & 70 & 78 \\
\hline 13 & Intan Aqilah Vinanda & 65 & 74 \\
\hline 14 & Jihan Wulandari & 60 & 75 \\
\hline 15 & Kisti Zahra Varagita & 75 & 79 \\
\hline 16 & Lidya Margareth Siregar & 60 & 70 \\
\hline 17 & Livia Febriyanti & 70 & 78 \\
\hline 18 & Luthfi Azahari & 65 & 70 \\
\hline 19 & Lutfan Kafi Maulana & 70 & 77 \\
\hline 20 & Maulana Malik Ibrahim & 60 & 74 \\
\hline 21 & Muhammad Syahrul Lackyn & 55 & 70 \\
\hline 22 & Noviana fitri & 50 & 60 \\
\hline 23 & Rani Octa Hidayanti & 55 & 70 \\
\hline 24 & Raka Radhitya afriza & 60 & 78 \\
\hline 25 & Salsabilla Azzahra & 70 & 70 \\
\hline 26 & Torus Manuela Pasaribu & 60 & 80 \\
\hline 27 & Uray Salsa Lefiananda & 60 & 70 \\
\hline \multirow[t]{2}{*}{28} & Yunisa Ahmadiyah & 65 & 78 \\
\hline & Rata-rata & 63,21 & 82,68 \\
\hline
\end{tabular}




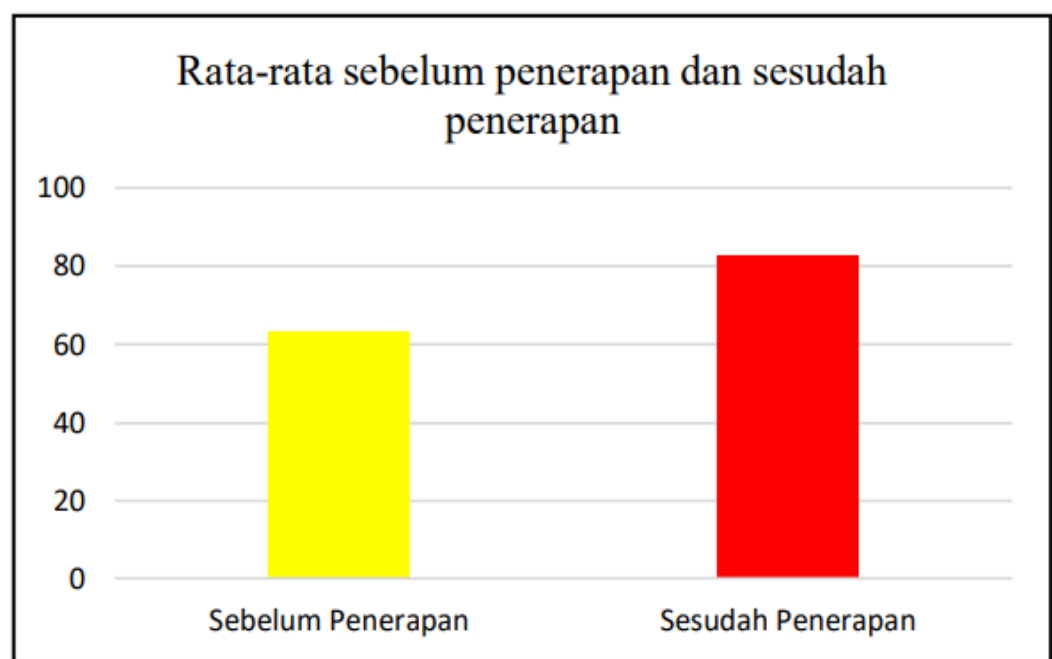

\section{Gambar 1. Data Hasil Evaluasi sebelum dan sesudah penerapan Pendekatan Konstruktivisme Berbantuan media Audio visual}

Berdasarkan gambar diatas dapat diketahui masih banyak siswa yang mendapatkan hasil belajar yang belum mencapai KKM sebelum penerapan pendekatan konstruktivisme berbantuan media audio-visual di lakukan. Dari jumlah siswa sebanyak 28 orang, yang memiliki nilai mencapai KKM (70) hanya 10 siswa atau setara 35,71\% sedangkan sisanya sebanyak 18 siswa atau setara dengan 64,28 siswa memiliki nilai di bawah KKM. Selanjutnya setelah penerapan pendekatan konstruktivisme berbantuan media audio-visual di lakukan hampir seluruh siswa 26 atau setara 82,68 \% siswa memperoleh hasil belajar sesuai KKM sedangkan 2 atau setara 7,14\% siswa memperoleh hasil belajar kurang dari KKM yaitu 70.

\section{Pembahasan}

Berdasarkan penelitian yag telah dilakukan, proses pembelajaran yang dilakukan dengan menerapkan pendekatan konstruktivisme berbantuan Media Audio Visual. Hasil observasi keterlaksanaan pembelajaran setelah menerapkan pendekatan konstruktivisme berbantuan Media Audio Visual mengalami peningkatan sebesar 82,68\%. Catatan lapangan yang telah dilakukan oleh observer menunjukan bahwa minat belajar siswa mengalami peningkatan. Selama proses pembelajaran berlangsung guru telah melaksanakan aktivitas pembelajaran dengan baik. Meskipun ada beberapa aspek yang belum sempurna yakni guru kurang menggali dan mengaitkan materi dengan pengetahuan yang relevan.

Konstruktivisme memandang perkembangan kognitif sebagai suatu hasil pertumbuhan dari perkembangan sosial melalui interaksi dengan orang lain yang terjadi dalam zona perkembangan terdekat anak-anak, dimana anak-anak dapat melakukan tugas-tugas baru yang berada dalam kemampuan meraka dengan bantuan guru atau teman sebaya. Diskusi merupakan komunikasi, dimana siswa berbicara dengan siswa yang lain, saling membagi gagasan dan pendapat. Di titik inilah salah satu peran penggunaan Media Pembelajaran Interaktif yang memungkinkan siswa agar lebih berinteraksi efektif dalam belajar. Sesuai pendapat Rusman (2011: 177) yang menyatakan bahwa penerapan media pembelajaran dapat mengembangkan kemampuan softskill dan hardskill siswa. Paling kurang penerapan multimedia pembelajaran memberikan beberapa nilai-nilai positif, seperti: (a) membantu siswa memahami konsep abstrak menjadi lebih konkrit, (b) memperkelas pesan, (c) kontekstual, (d) menimbulkan motivasi, kreativitas dan inovasi siswa dan (e) mengontrol kecepatan belajar siswa. 
Untuk menumbuhkan minat belajar siswa dibutuhkan sebuah Pendekatan Berbantuan media pembelajaran yang menarik yaitu media audio visual dimana media tersebut dapat melibatkan siswa dalam proses pembelajaran serta siswa diharapkan dapat berperan aktif dalam proses pembelajaran serta siswa dapat membangun kemampuan pengatahuan awalnya sendiri dengan bantuan media audiovisual, dimana siswa dapat mengoperasikan, mengontrol, dan melakukan evaluasi sendiri melalui media untuk mengukur ketercapaiannya proses pembelajaran. Media yang digunakan harus menarik minat siswa untuk belajar. Agar pembelajaran yang berlangsung tidak parsial, maka pembelajaran harus mencapai 3 ranah belajar. Jadi tidak hanya melihat kognitif saja, tetapi aspek motor skill dan afektif juga harus seimbang. Untuk itu media yang digunakan harus memenuhi ketiga aspek tersebut. Minat belajar siswa selain dipengaruhi oleh media yang digunakan, juga dipengaruhi oleh aktivitas siswa selama pembelajaran. Aktivitas siswa dalam mempelajari media pembelajaran interaktif dengan menggunakan aplikasi filmora ini memiliki tingkat frekuensi yang paling tinggi. Besarnya aktivitas siswa selama pembelajaran dapat menimbulkan pertanyaan dan pernyataan yang membuat siswa berpikir, sehingga penguatan konsep terhadap materi yang dipelajari akan lebih tinggi.

Ketuntasan dari hasil belajar siswa dapat dilihat dari nilai mata pelajaran PPKn materi integrasi nasional dalam bingkai bhineka tunggal ika yang didapatkan siswa. Ketuntasan hasil belajar ini dikatakan tercapai apabila pencapaian nilai $>80 \%$. Hasil tes yang dilakukan pada kegiatan pembelajaran di dapat dari 28 siswa, didapatkan 2 orang yang memiliki nilai rendah di bawah KKM (70), sedangkan 26 atau setara dengan 82,86\% siswa memperoleh nilai diatas KKM. Hasil nilai rata-rata secara keseluruhan menunjukkan bahwa seluruh siswa telah mencapai ketuntasan belajar dengan mengalami peningkatan hasil belajar.

Berdasarkan kajian yang di lakukan oleh peneliti menunujukan bahwa ada dampak positif dalam pelaksanaan Pendekatan Konstruktivisme berbantuan media audio-visual guna meningkatkan minat belajar siswa. Penerapan media ini dalam proses belajar mengajar dalam meningkatkan kemampuan kognitif, afektif, dan psikomotor. Hal ini karena ketika mengajar minat siswa dalam belajar menjadi bertambah (Intansari, 2010). Penerapan media interaktif ini tidak hanya membantu siswa dalam belajar tetapi dapat membantu guru dalam meningkatkan kompetensi professional yang dimilikinya. Peningkatan minat belajar ini didukung dengan penelitian yang dilakukan Himmah (2017) yang pada penelitiannya menunjukkan bahwa multimedia interaktif dapat meningkatkan hasil belajar siswa. selanjutnya penelitian yang dilakukan Wulandari (2020) yang menunjukan bahwa Media Pembelajaran Interaktif juga dapat Meningkatkan Minat Siswa Belajar Matematika. Hasil penelitian ini juga sejalan dengan penelitian Intansari (2010) yang menemukan bahwa Penggunaan Media CD Interaktif Untuk Meningkatkan Minat dan Hasil Belajar Dalam Mata Pelajaran Pendidikan Kewarganegaraan Siswa Kelas VII Bilingual . Jadi dengan meningkatnya hasil belajar siswa yang diperoleh dan didukung oleh penelitian-penelitian di atas, maka dapat dikatakan bahwa pendekatan konstruktivisme berbantuan media interaktif dapat meningkatkan minat belajar siswa, sehingga media ini dapat dikatakan sangat layak untuk digunakan sebagai media pembelajaran.

\section{KESIMPULAN}

Berdasarkan pembahasan masalah yang telah dipaparkan sebelumnya, maka dapat ditarik kesimpulan sebagai bahwa Pembelajaran PPKn dengan menggunakan pendekatan konstruktisme berbantuan media audio-visual dilakukan agar pembelajaran lebih variatif sehingga menarik minat belajar siswa, maka perlu dipersiapkan media yang dapat disesuaikan dengan irama belajar mereka, Media yang digunakan harus menarik minatnya untuk belajar. Agar pembelajaran yang berlangsung tidak parsial, maka pembelajaran harus mencapai 3 ranah belajar. Jadi tidak hanya melihat kognitif saja, tetapi aspek motor skill dan afektif juga harus seimbang. Untuk itu media yang digunakan harus memenuhi ketiga aspek tersebut. Ketika dilakukan evaluasi diperoleh hasil 
yang jauh meningkat jika dibandingkan dengan hasil belajar pada materi integrasi nasional dalam bingkai bhineka tunggal ika pada mata pelajaran PPKn sebelumnya dengan metode ceramah saja.

Dari 28 siswa hampir seluruh siswa 26 orang atau setara dengan 82,68\% mencapai ketuntasan belajar minimum yang ditetapkan pada pembelajaran PPKn sedangkan 2 orang atau setara dengan 7,14\% memperoleh hasil belajar di bawah KKM yaitu 70. Melalui penerapan Pendekatan Konstruktisme berbantuan media Audio-visual dapat menumbuhkan minat siswa dalam proses pembelajaran pada siswa Kelas XI IPA1 di SMA Negeri 3 Singkawang. Media Audio-visual yang disiapkan memiliki 6 tombol navigasi yang terdiri dari tombol : tombol pengantar yang terdiri dari petunjuk penggunaan media, motivasi dan pengantar materi, SK, KD \& Indikator Keberhasilan, tombol materi, tombol video dan soal.

\section{DAFTAR PUSTAKA}

Ajat Rukajat. (2018). Pendekatan Penelitian Kuantitatif: Quantitative Research Approach. Yogyakarta: Deepublish

Aritonang, K. T. (2008). Minat dan motivasi dalam meningkatkan hasil belajar siswa. Jurnal Pendidikan Penabur. No.10, hlm. 11-21.

Arsyad, Azhar. (2014). Media Pembelajaran Edisi Revisi. Jakarta: Rajawali Pers.

Aunurrahman. (2016). Belajar dan Pembelajaran, Bandung:Alfabeta

Daryanto. (2013). Media Pembelajaran. Yogyakarta: Gava Media

Himmah, Faiqotul dan Martini. (2017). "Pengembangan Multimedia Interaktif Menggunakan Inspring Suite 8 pada Sub Materi Zat Aditif untuk Meningkatkan Hasil Belajar Siswa SMP Kelas VIII". Jurnal Penelitian Pendidikan IPA FMIPA UNESA Surabaya

Intansari, D. (2010). "Penggunaan Media CD Interaktif Untuk Meningkatkan Minat dan Hasil Belajar Dalam Mata Pelajaran Pendidikan Kewarganegaraan Siswa Kelas VII Bilingual SMPN 2 Malang”. Jurnal S1 Program Studi Pendidikan Pancasila dan Kewarganegaraan.(67). Hlm. 79-83

Kemendikbud. (2006). Peraturan Menteri Pendidikan Nasional Republik Indonesia Nomor 22 Tahun 2006. Jakarta: Kemendikbud

Presiden Republik Indonesia. (2003_. Undang-Undang Republik Indonesia Nomor 20 Tahun 2003.Jakarta: Presiden Republik Indonesia

Rodiyana, Roni.(2018). Pengaruh Penerapan Strategi Quantum Learning Terhadap Motivasi dan Pemahaman Konsep Siswa. Jurnal Cakrawala Pendas.4, (2), 45-57

Rohmalia wahab, (2015). Psikologi Belajar. Palembang: Grafika Telindo Press.

Rusman, (2011). Pembelajaran Berbasis TIK. Jakarta: Raja Grafindo Persada.

Slameto, (2003). Belajar Dan Pembelajaran, Surabaya, Rahayu Cipto

Sudjana, Nana., dan Rivai, Ahmad. (2015). Media Pengajaran; Penggunaan dan Pembuatannya. Bandung: Sinar Baru Algesindo

Sukmadinata, Nana Syaodih. (2008). Pengembangan Kurikulum: Teori dan Praktek. Bandung: Remaja Rosdakarya Offset.

Sugiono. (2016). Metode Penelitian Kuantitatif, Kualitatif, dan R\&D. Bandung: Alfabeta.

Trianto.A (2017). Mendesain Model Pembelajaran Inovatif, Progresif dan Kontektual. Jakarta: Kencana

Wulandari, S. (2020). Media Pembelajaran Interaktif Untuk Meningkatkan Minat Siswa Belajar Matematika Di SMP 1 Bukit Sundi. Indonesian Journal of Technology, Informatics and Scienc 